\title{
New Zealand juvenile oyster mortality associated with ostreid herpesvirus 1 - an opportunistic longitudinal study
}

\author{
S. E. Keeling ${ }^{1,2, *}$, C. L. Brosnahan ${ }^{1}$, R. Williams ${ }^{1}$, E. Gias ${ }^{1}$, M. Hannah ${ }^{1}$, R. Bueno ${ }^{1}$, \\ W. L. McDonald ${ }^{1}$, C. Johnston ${ }^{1,3}$ \\ ${ }^{1}$ Animal Health Laboratory, Investigation and Diagnostic Centre - Wallaceville, Ministry for Primary Industries, 66 Ward St, \\ PO Box 40742, Upper Hutt 5018, New Zealand \\ ${ }^{2}$ Address for correspondence: Ministry for Primary Industries, Standards Branch, Science and Risk Assessment Directorate, \\ Pastoral House, 25 The Terrace, Wellington 6011, New Zealand \\ ${ }^{3}$ Present address: Aquaculture New Zealand, Level 1 Wakatu House, Montgomery Square, Nelson 7010, New Zealand
}

\begin{abstract}
During the 2010-11 summer outbreak of ostreid herpesvirus 1 (OsHV-1) in New Zealand, an opportunistic longitudinal field study was conducted. OsHV-1 PCR-negative oyster spat (Crassostrea gigas) were relocated to an OsHV-1 PCR-positive area of the North Island of New Zealand that was experiencing juvenile oyster mortalities. Over a period of $13 \mathrm{~d}$, spat were monitored for mortality, sampled for histopathology, and tested for the presence of OsHV-1 using real time PCR and Vibrio culture. Histopathology showed some evidence of tissue pathology; however, no consistent progressive pathology was apparent. Field mortalities were evident from Day 6 on. After 5 and $7 \mathrm{~d}$ of exposure, 83 and $100 \%$ of spat, respectively, tested positive for the virus by real time PCR. Vibrio species recovered during the longitudinal study included $V$. splendidus and $V$. aestuarianus. This study offers insight into the rapidity of onset and virulence of the virus in naïve oyster spat in New Zealand waters.
\end{abstract}

KEY WORDS: Ostreid herpesvirus $1 \cdot$ Vibrio $\cdot$ Crassostrea gigas

\section{INTRODUCTION}

Several species of marine bivalve molluscs have been affected by herpes-like viral infections, including the Pacific oyster Crassostrea gigas (Hine et al. 1992, Nicolas et al. 1992), the European oyster Ostrea edulis (Comps \& Cochennec 1993, da Silva et al. 2008), the Antipodean flat oyster O. angasi (Hine \& Thorne 1997), the Chilean oyster Tiostrea chilensis (Hine et al. 1998), the Manila clam Ruditapes philippinarum (Renault et al. 2001a,b), the Portuguese oyster C. angulata (Arzul et al. 2001b), the Suminoe oyster C. rivularis (Arzul et al. 2001b) and the French scallop Pecten maximus (Arzul et al. 2001a).
Reports of mortalities associated with herpes-like viruses have originated from several countries, including New Zealand (Hine et al. 1992), Australia (Hine \& Thorne 1997), France (Renault et al. 1994, 2009, Arzul et al. 2001a, 2002, Segarra et al. 2010), Ireland (Lynch et al. 2012, Peeler et al. 2012), Italy (Dundon et al. 2011), USA (Friedman et al. 2005, Burge et al. 2006, 2007, 2011), Spain (da Silva et al. 2008) and Mexico (Vasquez-Yeomans et al. 2004).

Following serious mortality events associated with herpes-like viral infections, extensive work has been undertaken on the virus. Initial characterisation of a herpes-like virus in a bivalve mollusc was described in Crassostrea virginica in the early 1970s (Farley et 
al. 1972). In 1999, Le Deuff and Renault undertook initial molecular characterisation of the virus infecting Pacific oysters (Le Deuff \& Renault 1999). This was followed up by the identification of the first variant (OsHV-1 Var) (Arzul et al. 2001a,b) and subsequent whole-genome sequencing of the ostreid herpesvirus 1 (OsHV-1; GenBank AY509253) (Davison et al. 2005). Segarra et al. (2010) published sequencing data on the emergence of the now problematic microvariant (OsHV-1 $\mu$ Var).

Several studies have identified other pathogens associated with major OsHV-1 mortality events in Europe. Vibrio species, including $V$. splendidus, $V$. aestuarianus and $V$. harveyi, have been isolated in association with OsHV-1 mortalities (Renault et al. 2009, Dégremont 2011, Schikorski et al. 2011a,b). Whilst Vibrio species are likely to be opportunistic pathogens, the significance of regular detection in association with OsHV-1 should not be overlooked. The major oyster mortality events in Europe are considered to be multi-factorial, with OsHV-1, Vibrio species and environmental conditions (e.g. increased water temperatures) all believed to contribute (Sauvage et al. 2009, Segarra et al. 2010, De Decker \& Saulnier 2011, De Decker et al. 2011).

During the summer of 2010-11 in New Zealand, OsHV-1, Vibrio species and warm water temperatures appeared to contribute to the deaths of juvenile C. gigas on the North Island of New Zealand. During the mortality event, the oyster industry provided access to pre-planned movements of apparently healthy hatchery-reared spat to an oyster growing site on the North Island where oyster mortalities attributed to OsHV-1 were occurring. This provided a unique opportunity to conduct a longitudinal study. This paper describes the molecular characterisation of the New Zealand OsHV-1 virus and results of the longitudinal study.

\section{MATERIALS AND METHODS}

\section{Longitudinal study}

Approximately 17000 Crassostrea gigas spat (60 d old animals) from a hatchery on the South Island were transferred using standard industry practice to an area on the North Island experiencing mortalities that were also PCR positive for OsHV-1. Spat transferred into the area the month prior to the longitudinal study had resulted in $100 \%$ mortality. The day before spat were due to leave the hatchery (referred to as Day -1), 30 were randomly sampled for histo- pathology and tested for OsHV-1 by real time PCR, and a subsample $(\mathrm{n}=10)$ was cultured for Vibrio species.

Once at the North Island site (Bay of Islands) (Day 0), spat were separated into mesh oyster bags containing approximately 300 spat, and put onto 2 lines with 28 bags on each line. The 2 lines were surrounded by farmed oysters in which mortality had been observed in the weeks prior to the transfer. Four designated bags of spat containing between 253 and 302 animals were observed during the study to assess mortality levels. The number of oyster spat in each bag was counted at the beginning of the trial. The number of dead oysters was counted and recorded every second day following transfer.

For laboratory testing, animals were randomly selected from other bags of transferred spat (i.e. those not being observed for mortality). Ten animals were taken from bags located at each end of 1 line, and 10 animals were taken from around the middle of the line of 28 bags, totalling $n=30$ per sampling day. Sampling for laboratory testing of field spat occurred on Days 1, 3, 5, 7, 9 and 13. No attempt to preferentially select moribund animals was made, and animals selected were alive at the time of sampling. Upon receipt at the laboratory, as for those animals sampled at Day -1 , samples were taken from each animal for histopathology, DNA was extracted for real time PCR testing, and a subsample ( $\mathrm{n}=10$ ) was cultured for Vibrio species. The average maximum water temperature during the study was $21^{\circ} \mathrm{C}$.

\section{Histopathology}

A transverse cut was made between labial palps and adductor muscle of the spat, and sections 2 to $5 \mathrm{~mm}$ thick were fixed in $10 \%$ sea water formalin. Fixed tissues were sent to IVABS (Institute of Veterinary, Animal and Biomedical Sciences, Massey University) for paraffin embedding, sectioning and staining (hematoxylin and eosin).

\section{DNA extraction}

Shells were removed from oyster spat, and approximately 10 to $20 \mathrm{mg}$ of tissue (primarily gills and mantle) was transferred to a sterile screw cap microfuge tube. Digest buffer (DX tissue digest, Qiagen) was added to each sample as per manufacturer's instructions and incubated overnight at $56^{\circ} \mathrm{C}$. Samples were 
then centrifuged, and a $220 \mu$ l aliquot was removed and transferred to a 96-well lysis block. The block was loaded onto an automated X-tractor Gene Robotic Instrument (Qiagen), and samples were extracted as per the manufacturer's protocol. Approximately $10 \%$ of samples per 96 -well plate were quantitated using Nanodrop (Thermo Scientific) or Qubit (Life Technologies).

\section{OsHV-1 real time PCR}

The primers and probe published by Martenot et al. (2010) were adapted for use with SsoFast probe mix and were optimised for use on the CFX96 real time PCR detection system (Bio-Rad) (Martenot et al. 2010). The primers and probe sequences used by Martenot et al. (2010) were forward primer 'OsHV1BF', reverse primer 'B4' and probe 'B'. Primer and probe concentrations were as per Martenot et al. (2010), except the reaction volume was $10 \mu \mathrm{l}$

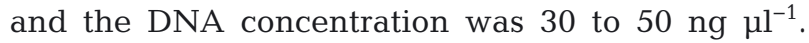
All samples were run with an upper $(4 \mu l)$ and lower $(1 \mu \mathrm{l})$ concentration of DNA to enable detection of viral load variations. Cycling parameters were $95^{\circ} \mathrm{C}$ for $2 \mathrm{~min}$ followed by 40 cycles of $95^{\circ} \mathrm{C}$ for $5 \mathrm{~s}$ and $60^{\circ} \mathrm{C}$ for $5 \mathrm{~s}$ (acquired to Texas red channel). DNA from infected tissue confirmed as positive for OsHV-1 by sequencing was used as a positive control in all assays.

An in-house 18S real time PCR for oysters was used to assess the suitability of the DNA for PCR. The primer pair Oys18SF1 (5'-ATC CAT TGG AGG GCA AGT CT-3') and Oys18SR1 (5'-CCA AGG GTT TAC AAC CGA GA-3') was used to amplify the 18S gene present in oysters. The reaction mix consisted of SsoFast EvaGreen Mix (Bio-Rad), $0.4 \mu \mathrm{M}$ of each primer,

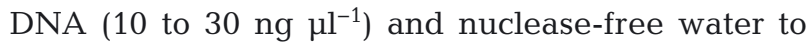
$10 \mu l$. Cycling parameters were $95^{\circ} \mathrm{C}$ for $2 \mathrm{~min}$ followed by 40 cycles of $95^{\circ} \mathrm{C}$ for $5 \mathrm{~s}$ and $60^{\circ} \mathrm{C}$ for $5 \mathrm{~s}$ (acquired to FAM channel), followed by a melt from 65 to $95^{\circ} \mathrm{C}\left(0.5^{\circ} \mathrm{C}\right.$ increments). A melt curve of $85.50^{\circ} \mathrm{C}$ was considered positive. (Note: no variation was observed in the melt temperature.)

\section{Initial characterisation of the New Zealand OsHV-1 strain}

Following DNA extraction, primers published by Renault \& Arzul (2001) were used to amplify the C2-C6 region (ORF4) to investigate the presence or absence of the $\mu$-variant trait (Renault \& Arzul 2001).
Briefly, the master mix consisted of $2 \times$ Kapa2G Fast Hotstart Taq (KapaBiosystems), primers $(0.1 \mu \mathrm{M}$ of each), DNA (50 to $100 \mathrm{ng} \mathrm{\mu l}^{-1}$ ) and nuclease-free water to $25 \mu \mathrm{l}$. PCR conditions consisted of $95^{\circ} \mathrm{C}$ for 2 min followed by 35 cycles of $95^{\circ} \mathrm{C}$ for $15 \mathrm{~s}, 50^{\circ} \mathrm{C}$ for $15 \mathrm{~s}$ and $72^{\circ} \mathrm{C}$ for $1 \mathrm{~s}$ (Veriti 96 well thermocycler, Applied Biosystems). Resulting products were electrophoresed on a $1.5 \%$ agarose gel in $1 \times$ Trisacetate-EDTA (TAE). Products approximately 690 bp in length were excised and purified using the Zymoclean Gel DNA recovery kit (Zymo Research Corporation). Purified DNA was sequenced using the primers C2 and C6 (Arzul et al. 2001b). Sequencing was performed by Ecogene, New Zealand. Geneious pro v5.4 was used to trim and assemble the sequences (Drummond et al. 2011), and Blast (Altschul et al. 1990) was then used to compare contigs with sequences available in GenBank.

\section{Vibrio culture}

A third of each batch of oyster spat $(n=10)$ was tested for Vibrio species on each sampling day and prior to leaving the hatchery. A small incision was made with a sterile blade into the muscle tissue, and a sterile swab was taken. The swab was then plated to thiosulphate-citrate-bile salt agar (Fort Richard) and incubated at $22^{\circ} \mathrm{C}$ for $48 \mathrm{~h}$. All resulting colonies from each sampling day were considered as a group from which representative colony types were selected. Suspect colonies were plated to blood agar (3\% NaCl) (Fort Richard) to check for purity. Blood agar (3\% salt) was used for sub-culturing as previous laboratory work had shown that this improved survivability of field isolates. Gram-staining and resistance to the vibriostatic reagent O/129 (150 $\mu \mathrm{g})$ (Oxoid) was then determined prior to molecular characterisation.

\section{Molecular characterisation of Vibrio species}

DNA was extracted using the DX kit for liquid samples and the automated X-tractor Gene Robotic Instrument as per manufacturer's instructions. Extracted DNA was amplified using the primers atpA06-R and atpA-04-R (Thompson et al. 2007). The master mix consisted of 1× Kapa2G Fast Hotstart

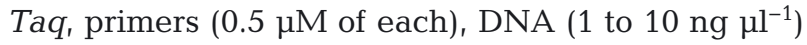
and nuclease-free water to $25 \mu$ l. PCR conditions consisted of $95^{\circ} \mathrm{C}$ for $2 \mathrm{~min}$ followed by 35 cycles of $95^{\circ} \mathrm{C}$ for $15 \mathrm{~s}, 58^{\circ} \mathrm{C}$ for $15 \mathrm{~s}$ and $72^{\circ} \mathrm{C}$ for $30 \mathrm{~s}$. Resulting 
products were electrophoresed on a $1.5 \%$ agarose gel in $1 \times$ TAE. Products approximately 1500 bp in length were excised and purified using the Zymoclean Gel DNA recovery kit).

Purified DNA was sequenced using the primers atpA-06-R, atpA-04-R, atpA-02-F and atpA-03-R (Thompson et al. 2007). Sequencing was performed by Ecogene, New Zealand. Geneious v5.4 was used to trim and assemble the sequences (Drummond et al. 2011). BlastN (Altschul et al. 1990) was then used to compare resulting contigs with sequences available in GenBank.

\section{RESULTS}

\section{Longitudinal study}

The following results present details of the histopathology observed, the incidence of OsHV-1 as measured by PCR and the associated Vibrio species identified during a longitudinal study that exposed apparently healthy spat to an area where OsHV-1 was detected.

\section{Histopathology}

Sections of Crassostrea gigas spat (Fig. 1) were examined on each of the sampling days to determine if a recognisable and progressive pathology could be noted. There were no detectable marked histological changes in gills, gonad, or digestive tract throughout the course of the longitudinal study. The main findings noted were in deep mantle tissues and the interstitial tissues, generally in the vicinity of elements of the digestive tract. The changes noted were an apparent increase in cellularity within the mantle or interstitial connective tissue. This increased cellularity, resembling haemocytosis, was either focal or diffuse and was noted on a number of occasions to be associated with the digestive tract, although no pathology was noted within the overlying digestive tract.

Day -1 samples (Fig. 1a,b) were used as a baseline with which to compare subsequent sampling events. Whilst there were some areas that displayed obvious increased cellularity of the interstitial tissue around the time of peak OsHV-1 infection (Fig. 1d), with some apparent loss of cellular integrity (Fig. 1f), this was by no means a consistent finding. The changes varied within each group and, while some animals displayed obvious changes, others appeared to have either minimal or no pathology (Fig. 1h). Despite careful observation, no instances of intranuclear inclusion bodies were noted.

\section{OsHV-1 incidence as measured by real time PCR}

Spat $(n=30)$ tested negative for OsHV-1 by real time PCR prior to leaving the hatchery (Day -1). On Days 1 and $3,7 \%$ of spat were positive for OsHV-1 by real time PCR. On Day 5, 93\% of spat were positive, on Days 7 and 9, $100 \%$ of spat were positive and on Day 13, $93 \%$ were positive for OsHV-1 (Fig. 2). Field mortality was not observed until Day 6. Observed mean mortalities were 14,50 and 70\% on Days 6, 9 and 13, respectively. During the study there was also evidence of an increase in viral load. For samples that tested positive on Days 1 and 3, a mean $( \pm \mathrm{SD})$ Cq value of 37 \pm 0.7 was recorded. On Day 5 , a mean $( \pm \mathrm{SD}) \mathrm{Cq}$ value of $30 \pm 6.5$ was recorded, and on Days 7, 9 and 13, mean $( \pm \mathrm{SD})$ Cq values of $25 \pm 4.6,24 \pm 5.0$ and $29 \pm 2.6$ were recorded, respectively. Testing ceased after Day 13 , as spat were significantly affected and not deemed suitable for analyses due to tissue degradation. All spat samples tested positive for the oyster $18 \mathrm{~S}$ real time PCR, indicating suitability for PCR.

\section{Characterisation of the New Zealand OsHV-1 specimen}

The GenBank sequence (JN639858) relevant to this study is representative of 17 specimens from various North Island New Zealand locations collected in 1999 (Coromandel; $\mathrm{n}=5$ ), 2010 (Mahurangi Harbour, Dyers Creek, Kaipara, Bay of Islands; $\mathrm{n}=8$ ), 2011 (Bay of Islands; $\mathrm{n}=2$ ) and 2012 (Houhora harbour; $\mathrm{n}=2$ ). Unlike the specimens from 2010, 2011 and 2012, the specimens from 1999 were not associated with a mortality event and were recovered from formalin-fixed tissue. The results of the comparative sequence analysis of the $\mathrm{C} 2-\mathrm{C} 6$ region associated with ORF4 with the reference (GenBank AY509253) and $\mu$-variant sequences (GenBank HQ842610) indicate that the New Zealand specimens (GenBank JN639858) in this study were similar to the $\mu$-variant sequence, with the exception of 2 mutations. This difference with HQ842610 was also reported for other samples of New Zealand origin by Renault et al. (2012). However, the sequence in this study also differs from the samples of New Zealand origin published by Renault et al. (2012) by a single mutation. Interestingly, the sequence in this study is identical 

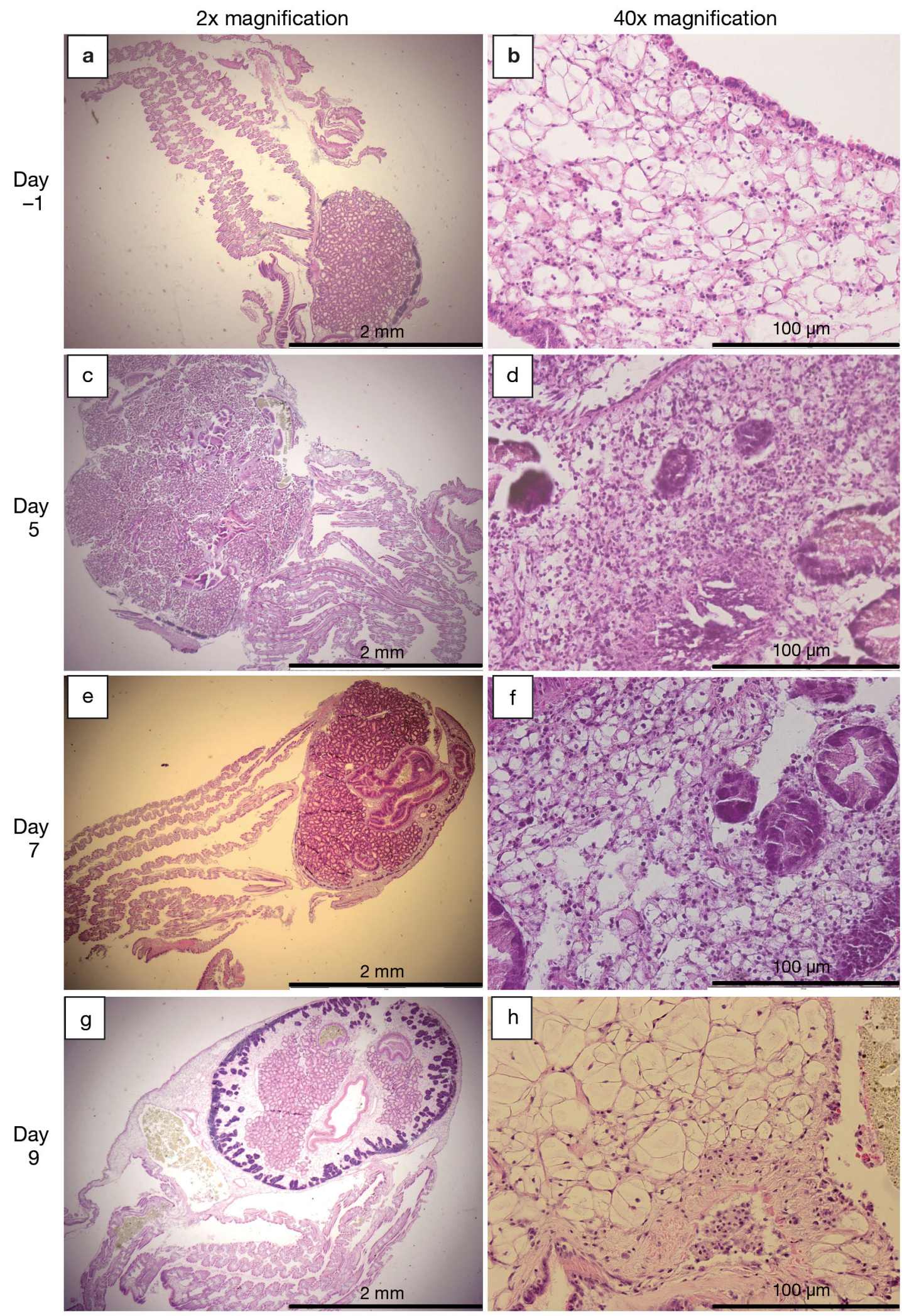

Fig. 1. Representative cross sections of Crassostrea gigas spat examined on each sampling day: (a,b) prior to transfer to the study location (Day -1) and (c-h) after transfer. (c,d) Day 5 (note increased cellularity); (e,f) Day 7 (note increased cellularity and loss of cell integrity); $(g, h)$ Day 9 (note the few apparent pathological changes in this indiviudal despite high mortality and infection prevalence rates in the cohort). $(\mathrm{a}, \mathrm{c}, \mathrm{e}, \mathrm{g})$ Cross section; (b) mantle tissue, $(\mathrm{d}, \mathrm{f}, \mathrm{h})$ interstitial tissue near digestive tubules 
to a specimen from Japan, AB734065 (Shimahara et al. 2012). When comparing JN639858 with the reference sequence (AY509253), there are several substitutions and deletions. The main deletion of 13 consecutive nucleic acids in a microsatellite region is characterised by CTA repeats (Fig. 3), a deletion also evident in the variant $\mu \operatorname{Var}(\mathrm{HQ842610)}$.

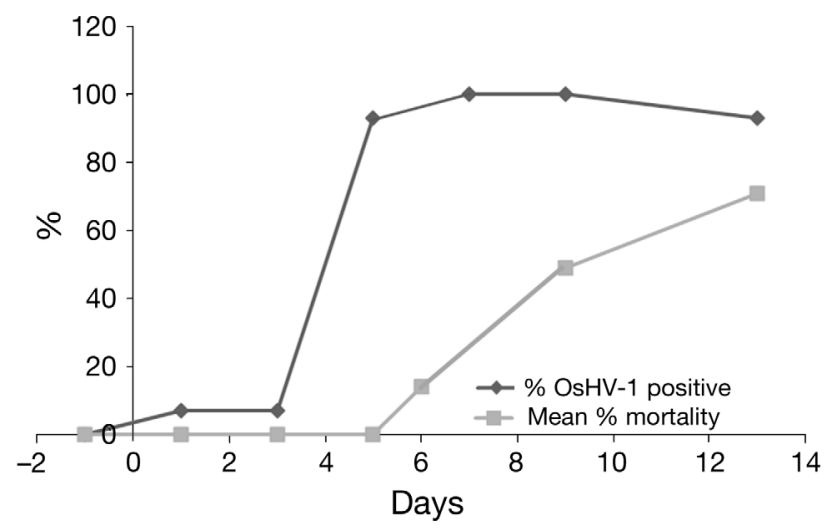

Fig. 2. Incidence of ostreid herpesvirus $1(\mathrm{OsHV}-1)$ as measured by real time PCR during the longitudinal study, and observed percentage mortality. Results are for $n=30$ spat for each sampling day

\section{Molecular characterisation of Vibrio species}

Several Vibrio species were identified following sequence analysis of the atpA gene, with $V$. splendidus being detected on more than 1 sampling day (Table 1). $V$. alginolyticus was recovered in pure growth from the hatchery samples, whereas growth observed in the field was moderate to heavy mixed growth. Only colonies showing commonality and dominance across samples were selected for sequencing.

Table 1. Vibrio species identified during the longitudinal study

\begin{tabular}{|ll|}
\hline Day & Vibrio species \\
\hline 1 & V. alginolyticus \\
3 & V. splendidus \\
5 & V. splendidus, V. chagassi \\
7 & V. splendidus \\
9 & V. alginolyticus, V. chagassi \\
13 & V. splendidus, V. aestuarianus, V. alginolyticus \\
\end{tabular}

HQ842610 OsHV-1 microVar JN639858 NZ-OsHV-1 AY509253 OsHV-1

HQ842610 OsHV-1 microVar JN639858 NZ-OsHV-1 AY509253 OsHV-1

HQ842610 OsHV-1 microvar JN639858 NZ-OsHV-1 AY509253 OsHV-1

HQ842610 OsHV-1 microVar JN639858 NZ-OsHV-1 AY509253 OsHV-1

HQ842610 OsHV-1 microVar JN639858 NZ-OsHV-1 AY509253 OsHV-1

HQ842610 OsHV-1 microVar JN639858 NZ-OsHV-1 AY509253 OsHV-1

HQ842610 OsHV-1 microvar JN639858 NZ-OsHV-1 AY509253 OsHV-1 $\begin{array}{lllllll}1 & 10 & 20 & 30 & 40 & 50 & 60 \\ \mid & \mid & \mid & \mid & \mid & \mid & \mid\end{array}$ AAACCTAACGTTGTATTCGATTACGGATTAAGAAAATGGGTTCCACAATCTAAAATTAAA AAACCTAACGTTGTATTCGATTACGGATTAAGAAAATGGGTTCCACAATCTAAAATTAAA AAACCTAACGTTGTATTCGATTACGGATTAAGAAAATGGGTTCCACAATCTAAAATTAAA

- AACCCACATGGGGGCCAAGGAATTTAAAGCCCCGGGGAAAAAAGTATAAATAGGCGCGA - AACCCACATGGGGGCCAAGGAATTTAAAGCCCCGGGGAAAAAAGTATAAATAGGCGCGA AAAACCACATGGGGGCCAAGGAATTTAAA- CCCCGGGG - AAAAAGTATAAATAGGCGCGA

TTTGTCAGTTTAGAATCATACC - - CACACTCAATCTCGAGTATACCACAACTGCTAAATT TTTGTCAGTTTAGAATCATACC - CACACTCAATCTCGAGTATACCACAACTGCTAAATT TTTGTCAGTTTAGAATCATACCCACACACTCAATCTCGAGTATACCACAACTGCTAAATT

AACAGCATCTACTACTACTACTG - - - - - - - - AAAAATGCAGCCTTTCACAGAATT AACAGCATCTACTACTACTACTG- - - - - - - - AAAAATGCAGCCTTTCACAGAATT AACAGCATCTACTACTACTACTACTACTACTACTGAAAAAATGCAGCCTTTCACAGAATT

TTGCACCTTGACCAAAGCCATCACATCAGCCAGCAACGACTTTTTCATCAACCAGACGAG TTGCACCTTGACCAAAGCCATCACATCAGCCAGCAACGACTTTTTCATCAACCAGACGAG TTGCACCTTGACCAAAGCCATCACATCAGCCAGCAACGACTTTTTCATCAACCAGACGAG

GTTAACATGCGACATTTGTAAAGAGCTCGTCTCTTTCAATTGCAAAGATAAAGTCGTGGC GTTAACATGCGACATTTGTAAAGAGCTCGTCTCTTTCGATTGCGAAGATAAAGTCGTGGC GTTAACATGCGACATTTGTAAAGAGCTCGTCTCTTTCGATTGCGAAGATAAAGTCGTGGC

ATCATTGGCTGCAGTCAGATCTGACATACCCATAGAAGTCACGGAACGCAAAGACCTGAA ATCATTGGCTGCAGTCAGATCTGACATACCCATAGAAGTCACGGAACGCAAAGACCTGAA ATCATTGGCTGCAGTCAGATCTGACATACCCATAGAAGTCACGGAACGCAAAGACCTGAA

Fig. 3. DNA sequence alignment of the C2-C6 $\mu$-variant region of the New Zealand OsHV-1 specimen (JN639858) with OsHV-1 (AY509253) and the $\mu$ Var strain of OsHV-1 (HQ842610) 


\section{DISCUSSION}

The longitudinal study conducted during the 2010-11 juvenile oyster (Crassostrea gigas) mortality event was considered an opportunistic study that took advantage of pre-planned spat (PCR-negative) movements by the oyster industry from a hatchery on the South Island to a North Island growing site where the OsHV-1 virus appeared active. It was not possible to transfer spat at the same time to a known uninfected area in order to assess the influence of transportation on animal viability. Further, the study was conducted during the outbreak; hence, the OsHV-1 status in other growing regions of similar climatic conditions was not known at the time. However, the results of the study have provided useful insight into the behaviour of the virus from the initial exposure of apparently healthy animals to a known infected site, viral replication, PCR detectable levels and subsequent mortalities.

The rapidity of viral replication in the field was evident by real time PCR detection of the virus in $83 \%$ of the animals $5 \mathrm{~d}$ after exposure and by $50 \%$ observed mortalities after 9 d. Laboratory studies have shown that intramuscular injection of $1 \mathrm{yr}$ old oysters with viral suspensions induces up to $80 \%$ mortality within $4 \mathrm{~d}$ (Schikorski et al. 2011a). Co-habitation studies showed that healthy oysters develop the disease after $2 \mathrm{~d}$ of co-habitation with experimentally infected oysters (Schikorski et al. 2011a). The earlier occurrence of mortalities in laboratory studies compared to those in the field longitudinal study was not unexpected. In the laboratory studies, a standardised viral dose could be used and the laboratory studies were not subjected to tidal flows changing the concentration of the virus in sea water. Furthermore, the laboratory studies focused primarily on selectively exposing laboratory animals to bacterium-free filtrate derived from OsHV-1infected oysters, thereby demonstrating the pathogenicity of the virus alone (Schikorski et al. 2011a,b). However, neither study compared the homogenates (with and without the presence of bacteria) used to infect the oysters in challenge studies, so it is hard to compare the mortality rates of field and laboratory studies directly.

The virus variant $\mu$ Var has emerged in Europe as a main contributing factor to the oyster mortality events that have significantly impacted oyster growing areas since 2008 (Segarra et al. 2010, Garcia et al. 2011). From a molecular perspective, several variations from the reference genome described by Davison et al. (2005) exist for $\mu$ Var (Davison et al. 2005).
These include several polymorphisms and a microsatellite zone with several deletions present in the $\mathrm{C}$ region (ORF4) and the IA region (ORF43) of the $\mu \mathrm{Var}$ genome (Segarra et al. 2010). ORF4 was selected as the region to use for characterisation, as Segarra et al. (2010) reported this region to have more variation than ORF43.

Sequencing of the $\mathrm{C} 2-\mathrm{C} 6$ region (ORF4) indicated that both the New Zealand specimen (JN639858) and the virus variant $\mu$ Var share similar variations compared to the reference sequence (AY509253) (Fig. 3). Of most significance is the same distinguishing deletion of 13 consecutive nucleic acids in the microsatellite region characterised by CTA repeats (Segarra et al. 2010). The New Zealand specimen in this study also has 2 nucleotides in common with OsHV-1 (AY509253) that differ from the virus variant $\mu$ Var (HQ842610) (Fig. 3). Further, comparison with recently published sequences in GenBank indicates a high percentage similarity (99 to $100 \%$ ) with other virus micro-variants, including other samples collected during the 2010 mortality event in New Zealand. The single-base mutation observed between the New Zealand specimens described in this study and those described by Renault et al. (2012) (JN800130 \& JN800131) may be the result of technical sequence variation or a genuine mutation.

The identification of several Vibrio species during the study, particularly $V$. splendidus and $V$. aestuarianus, correlates well with European mortality events (Le Roux et al. 2002, Sauvage et al. 2009, Segarra et al. 2010). However, V. alginolyticus, which was the dominant Vibrio species recovered from the spat at the hatchery (Day -1), has also been associated with mortalities in marine bivalves (Gómez-León et al. 2005). Its pathogenicity is potentially due to the production of an extracellular toxin (Nottage \& Birkbeck $1987 a, 1987 b)$ which may have influenced the susceptibility of spat to infection with OsHV-1 in the field. $V$. aestuarianus and $V$. splendidus also produce extracellular products that are toxic for marine bivalves (Labreuche et al. 2006, Binesse et al. 2008), which may have had an impact on the health of oyster spat in the field.

Identification of key Vibrio species in addition to OsHV-1 suggests that the cause of the mortalities observed during the longitudinal study was multifactorial, with environmental conditions potentially contributing as well. Pernet et al. (2010) reported oyster mortality occurred during the reproductive season when sea water temperature was $>19^{\circ} \mathrm{C}$ (Pernet et al. 2010). The average water temperature during the New Zealand longitudinal study was $21^{\circ} \mathrm{C}$. 
Given that this was the first significant mortality event in New Zealand, it is not possible to conclusively identify sea water temperature as a contributing factor. This may only become apparent if major mortality events become an ongoing problem for the New Zealand oyster industry.

The presence of a herpes-like virus in New Zealand in bivalve molluscs was first reported in 1992 from hatchery-reared larval $C$. gigas and was characterised based on TEM (Hine et al. 1992). A survey of several bivalve species undertaken in 2007 in New Zealand using PCR did not detect any OsHV-1 DNA (Webb et al. 2007). However, this study focused on fixed tissue, and no clinically affected animals were available during the survey. The juvenile oyster mortality event during the 2010-11 New Zealand summer presented a valuable opportunity to undertake molecular characterisation of the New Zealand OsHV-1 type.

The New Zealand OsHV-1 type is similar to other variants related to the variant $\mu$ Var based on the limited sequence analysed. In the longitudinal study, the concurrent presence of OsHV-1, pathogenic Vibrio species and warm-water temperatures in association with the high mortality of juvenile Pacific oysters supports the notion that a multi-factorial event took place in the summer of 2010-11 in New Zealand. Results of the present study indicate the need for further research in New Zealand in order to help the oyster industry overcome potential long-term impacts of the virus. The Ministry for Primary Industries' Animal Health Laboratory at the Investigation and Diagnostic Centre, Wallaceville, has undertaken further work in the area, including metagenomic next-generation sequencing of infected larvae. This work will help to advance knowledge of the New Zealand virus and of the influence of other potential disease agents.

Acknowledgements. The authors thank all the staff members at the Animal Health Laboratory at the Investigation and Diagnostic Centre, Wallaceville, who assisted with diagnostic testing during the juvenile oyster mortality event of 2010-11. We also thank Ian Herbert from Pacific Marine Farms, for his assistance during the longitudinal study, and the Cawthron Research Institute for the supply of spat.

\section{LITERATURE CITED}

Altschul SF, Gish W, Miller W, Myers EW, Lipman DJ (1990) Basic local alignment search tool. J Mol Biol 215:403-410

Arzul I, Nicolas JL, Davison AJ, Renault T (2001a) French scallops: a new host for ostreid herpesvirus-1. Virology 290:342-349

> Arzul I, Renault T, Lipart C, Davison AJ (2001b) Evidence for interspecies transmission of oyster herpesvirus in marine bivalves. J Gen Virol 82:865-870

Arzul I, Renault T, Thébault A, Gérard A (2002) Detection of oyster herpesvirus DNA and proteins in asymptomatic Crassostrea gigas adults. Virus Res 84:151-160

Binesse J, Delsert C, Saulnier D, Champomier-Verges MC and others (2008) Metalloprotease Vsm is the major determinant of toxicity for extracellular products of Vibrio splendidus. Appl Environ Microbiol 74:7108-7017

$>$ Burge CA, Griffin FJ, Friedman CS (2006) Mortality and herpesvirus infections of the Pacific oyster Crassostrea gigas in Tomales Bay, California, USA. Dis Aquat Org 72: 31-43

- Burge CA, Judah LR, Conquest LL, Griffin FJ and others (2007) Summer seed mortality of the Pacific oyster, Crassostrea gigas Thunberg grown in Tomales Bay, California, USA: the influence of oyster stock, planting time, pathogens, and environmental stressors. J Shellfish Res 26:163-172

> Burge CA, Strenge RE, Friedman CS (2011) Detection of the oyster herpesvirus in commercial bivalves in northern California, USA: conventional and quantitative PCR. Dis Aquat Org 94:107-116

Comps M, Cochennec N (1993) A herpes-like virus from the European oyster Ostrea edulis L. J Invertebr Pathol 62: 201-203

da Silva PM, Renault T, Fuentes J, Villalba A (2008) Herpesvirus infection in European flat oysters Ostrea edulis obtained from brood stocks of various geographic origins and grown in Galicia (NW Spain). Dis Aquat Org 78: 181-188

> Davison AJ, Trus BL, Cheng N, Steven AC and others (2005) A novel class of herpesvirus with bivalve hosts. J Gen Virol 86:41-53

> De Decker S, Saulnier D (2011) Vibriosis induced by experimental cohabitation in Crassostrea gigas: evidence of early infection and down-expression of immune-related genes. Fish Shellfish Immunol 30:691-699

De Decker S, Normand J, Saulnier D, Pernet F, Castagnet S, Boudry P (2011) Responses of diploid and triploid Pacific oysters Crassostrea gigas to Vibrio infection in relation to their reproductive status. J Invertebr Pathol

> Dégremont L (2011) Evidence of herpesvirus (OsHV-1) resistance in juvenile Crassostrea gigas selected for high resistance to the summer mortality phenomenon. Aquaculture 317:94-95

Drummond AJ, Ashton B, Buxton S, Cheung M and others (2011) Geneious v5.4. Biomatters, Auckland

Dundon WG, Arzul I, Omnes E, Robert M and others (2011) Detection of Type 1 Ostreid Herpes variant (OsHV1 uvar) with no associated mortality in French-origin Pacific cupped oyster Crassostrea gigas farmed in Italy. Aquaculture 314:49-52

Farley CA, Banfield WG, Kasnic G, Foster WS (1972) Oyster herpes-type virus. Science 178:759-760

> Friedman CS, Estes RM, Stokes NA, Burge CA and others (2005) Herpes virus in juvenile Pacific oysters Crassostrea gigas from Tomales Bay, California, coincides with summer mortality episodes. Dis Aquat Org 63:33-41

> Garcia C, Thébault A, Dégremont L, Arzul I and others (2011) Ostreid herpesvirus 1 detection and relationship with Crassostrea gigas spat mortality in France between 1998 and 2006. Vet Res 42:73

- Gómez-León J, Villamil L, Lemos ML, Novoa B, Figueras A (2005) Isolation of Vibrio alginolyticus and Vibrio splen- 
didus from aquacultured carpet shell clam (Ruditapes decussatus) larvae associated with mass mortalities. Appl Environ Microbiol 71:98-104

Hine PM, Thorne T (1997) Replication of herpes-like viruses in haemocytes of adult flat oysters Ostrea angasi: an ultrastructural study. Dis Aquat Org 29:189-196

> Hine PM, Wesney B, Hay BE (1992) Herpesviruses associated with mortalities among hatchery-reared larval Pacific oysters Crassostrea gigas. Dis Aquat Org 12: 135-142

Hine P, Wesnay B, Basant P (1998) Replication of a herpeslike virus in larvae of the flat oyster Tiostrea chilensis at ambient temperatures. Dis Aquat Org 32:161-171

Labreuche Y, Soudant P, Gonçalves M, Lambert C, Nicolas JL (2006) Effects of extracellular products from the pathogenic Vibrio aestuarianus strain 01/32 on lethality and cellular immune responses of the oyster Crassostrea gigas. Dev Comp Immunol 30:367-379

Le Deuff RM, Renault T (1999) Purification and partial genome characterization of a herpes-like virus infecting the Japanese oyster, Crassostrea gigas. J Gen Virol 80: 1317-1322

> Le Roux F, Gay M, Lambert C, Waechter M and others (2002) Comparative analysis of Vibrio splendidus-related strains isolated during Crassostrea gigas mortality events. Aquat Living Resour 15:251-258

> Lynch SA, Carlsson J, Reilly AO, Cotter E, Culloty SC (2012) A previously undescribed ostreid herpes virus 1 (OsHV1) genotype detected in the Pacific oyster, Crassostrea gigas, in Ireland. Parasitology 126:1526-1532

Martenot C, Oden E, Travaillé E, Malas JP, Houssin M (2010) Comparison of two real-time PCR methods for detection of ostreid herpesvirus 1 in the Pacific oyster Crassostrea gigas. J Virol Methods 170:86-89

Nicolas JL, Comps M, Cochennec N (1992) Herpes-like virus infecting Pacific-oyster larvae, Crassostrea gigas. Bull Eur Assoc Fish Pathol 12:11-13

> Nottage AS, Birkbeck TH (1987a) Purification of a proteinase produced by the bivalve pathogen Vibrio alginolyticus NCMB 1339. J Fish Dis 10:211-220

> Nottage AS, Birkbeck TH (1987b) Production of proteinase during experimental infection of Ostrea edulis L. larvae with Vibrio alginolyticus NCMB 1339 and the antigenic relationship between proteinases produced by marine vibrios pathogenic for fish and shellfish. J Fish Dis 10: 265-273

> Peeler EJ, Reese RA, Cheslett DL, Geoghegan F, Power A, Thrush MA (2012) Investigation of mortality in Pacific oysters associated with Ostreid herpesvirus-1 $\mu$ Var in the Republic of Ireland in 2009. Prev Vet Med 105:136-143

> Pernet F, Barret J, Marty C, Moal J, Le Gall P, Boudry P (2010) Environmental anomalies, energetic reserves and fatty acid modifications in oysters coincide with an exceptional mortality event. Mar Ecol Prog Ser 401: 129-146

Renault T, Arzul I (2001) Herpes-like virus infections in

Editorial responsibility: Rebecca Gast,

Woods Hole, Massachusetts, USA hatchery-reared bivalve larvae in Europe: specific viral DNA detection by PCR. J Fish Dis 24:161-168

Renault T, Le Deuff RM, Cochennec N, Maffart P (1994) Herpesviruses associated with mortalities among $\mathrm{Pa}-$ cific oyster, Crassostrea gigas, in France-comparative study. Rev Med Vet 145:735-742

> Renault T, Lipart C, Arzul I (2001a) A herpes-like virus infects a non-ostreid bivalve species: virus replication in Ruditapes philippinarum larvae. Dis Aquat Org 45:1-7

$>$ Renault T, Lipart C, Arzul I (2001b) A herpes-like virus infecting Crassostrea gigas and Ruditapes philippinarum larvae in France. J Fish Dis 24:369-376

Renault T, Allain G, Arzul I, Chollet B and others (2009) Summer mortality outbreaks of French Pacific oysters Crassostrea gigas in 2008 and 2009. In: Proc 14th EAFP Int Conf: Diseases of fish and shellfish, 14-17 Sept 2009, Prague. http://archimer.ifremer.fr/doc/00014/12554

- Renault T, Moreau P, Faury N, Pepin JF, Segarra A, Webb S (2012) Analysis of clinical ostreid herpesvirus 1 (Malacoherpesviridae) specimens by sequencing amplified fragments from three virus genome areas. J Virol 86:5942-5947

Sauvage C, Pépin JF, Lapègue S, Boudry P, Renault T (2009) Ostreid herpes virus 1 infection in families of the Pacific oyster, Crassostrea gigas, during a summer mortality outbreak: differences in viral DNA detection and quantification using real-time PCR. Virus Res 142:181-187

> Schikorski D, Faury N, Pepin JF, Saulnier D, Tourbiez D, Renault T (2011a) Experimental ostreid herpesvirus 1 (OsHV-1) infection of the Pacific oyster Crassostrea gigas: kinetics of virus DNA detection by q-PCR in seawater and in oyster samples. Virus Res 155:28-34

Schikorski D, Renault T, Saulnier D, Faury N, Moreau P, Pépin JF (2011b) Experimental infection of Pacific oyster Crassostrea gigas spat by ostreid herpesvirus 1: demonstration of oyster spat susceptibility. Vet Res 42:27

> Segarra A, Pépin JF, Arzul I, Morga B, Faury N, Renault T (2010) Detection and description of a particular Ostreid herpesvirus 1 genotype associated with massive mortality outbreaks of Pacific oysters, Crassostrea gigas, in France in 2008. Virus Res 153:92-99

Shimahara Y, Kurita J, Kiryu I, Nishioka T and others (2012) Surveillance of Type 1 ostreid herpesvirus (OsHV-1) variants in Japan. Fish Pathol 47:129-136

> Thompson CC, Thompson FL, Vicente ACP, Swings J (2007) Phylogenetic analysis of vibrios and related species by means of atpA gene sequences. Int J Syst Evol Microbiol $57: 2480-2484$

Vasquez-Yeomans R, Caceres-Martinez J, Huerta AF (2004) Herpes-like virus associated with eroded gills of the Pacific oyster Crassostrea gigas in Mexico. J Shellfish Res 23:417-420

> Webb SC, Fidler A, Renault T (2007) Primers for PCR-based detection of ostreid herpes virus-1 (OsHV-1): application in a survey of New Zealand molluscs. Aquaculture 272: 126-139

Submitted: February 28, 2013; Accepted: February 18, 2014 Proofs received from author(s): May 15, 2014 